\title{
Anti-HIV-1 protease activities of crude extracts of some Garcinia species growing in Tanzania
}

\author{
Joseph J. Magadula ${ }^{1 *}$ and Supinya Tewtrakul ${ }^{2}$ \\ ${ }^{1}$ Institute of Traditional Medicine, Muhimbili University of Health and Allied Sciences, Box 65001, Dar Es Salaam, \\ Tanzania. \\ ${ }^{2}$ Department of Pharmacognosy and Pharmaceutical Botany, Faculty of Pharmaceutical Sciences, Prince of Songkla \\ University, Hat-Yai, Songkhla, 90112, Thailand.
}

Accepted 11 June, 2009

\begin{abstract}
Eighteenth ethanol extracts from some Garcinia species in the Guttiferae (Clusiaceae) family collected in Tanzania were investigated for their HIV-1 protease (HIV-1 PR) inhibitory activities using high performance liquid chromatography (HPLC). Among the tested extracts, the fruit hulls of Garcinia semseii showed the most potent inhibitory activity against HIV-1 PR with an $\mathrm{IC}_{50}$ value of $5.7 \mu \mathrm{g} / \mathrm{ml}$ followed by the stem bark extracts of Garcinia edulis and Garcinia kingaensis with ${ }^{1} \mathrm{C}_{50}$ values of 9.2 and $15.2 \mu \mathrm{g} / \mathrm{ml}$, respectively. Phytochemical screening of extracts indicated mostly the presence of phenolic and steroidal compounds.
\end{abstract}

Key words: Garcinia species, clusiaceae, crude extracts, HIV-1 protease, inhibitory effect.

\section{INTRODUCTION}

Acquired immunodeficiency syndrome (AIDS) crisis is one of the greatest public health and humanitarian challenges in our time. In the two decades since the disease was first diagnosed, 20 million lives have been succumbed of AIDS. Currently, over 30.8 million people are infected with HIV/AIDS and $95 \%$ of them live in the developing countries (UN-AIDS Report, 2005 and 2007). The causative organism in AIDS is the human immunodeficiency virus type 1 (HIV-1) which is the member of retrovirus family. One of the enzymes that is responsible in the life cycle of the virus is the HIV-1 protease (PR) which process viral proteins into functional enzymes and structural proteins. HIV-1 PR plays a key role in the maturity and infectivity of the virus hence it has become an important target in HIV drug development (Kohl et al., 1988). HIV-1 PR function as a protein dimer of $11 \mathrm{kDa}$ each, that possess a residue of Asp-Thr-Gly as the catalytic site, and the amino acid subjected to the cleavage by protease includes Phe-Pro, Pro-Tyr and Leu-Phe in the polyprotein (Oroszlam, 1989). The investigation of Tanzanian Garcinia plant species as HIV-1 inhibitors has been initiated as the

${ }^{\star}$ Corresponding author. E-mail: jmagadula@yahoo.co.uk. Tel: +25522 2150096. Fax: +255222150465. alternative strategy to supplement the existing HIV-PR inhibitors such as nelfinavir, amprenavir and saquinavir that have been reported to develop resistance and some side effects (Borman et al., 1996). Few Garcinia species reported in the literatures have been investigated for their HIV-1 PR inhibitory effects. These include Garcinia mangostana which gave mangostin, a compound that indicated significant HIV-1 protease inhibition (Chen et al., 1996). Garcinia livingstoneii has been reported to produce gutifferone $\mathrm{A}$, being an anti-HIV compound (Gustafson, et al., 1992). Furthermore, other genera of the family clusiaceae showed interesting and strong activity in inhibiting the PR and RT enzymes such as coumarin derivatives (Reyes et al., 2004).

This paper reports the results of anti-HIV-1 protease activity screening of some Tanzanian medicinal plants of the genus Garcinia (Clusiaceae). Eighteen extracts from nine Garcinia species collected from different parts in Tanzania were investigated (Tables 1 and 2).

\section{MATERIALS AND METHODS}

Plant materials

The plant materials were identified by Mr. Haji O. Suleimani of the Department of Botany, University of Dar es Salaam. They include 
Table 1. Phytochemical screening of the extracts from some Garcinia species.

\begin{tabular}{|c|c|c|c|c|c|c|c|c|c|}
\hline \multirow[b]{2}{*}{$\mathbf{S} / \mathbf{N}$} & \multirow[b]{2}{*}{ Plant name } & \multirow{2}{*}{$\begin{array}{l}\text { Voucher } \\
\text { specimen }\end{array}$} & \multirow{2}{*}{$\begin{array}{l}\text { Locality in } \\
\text { Tanzania }\end{array}$} & \multirow[b]{2}{*}{ Part } & \multicolumn{5}{|c|}{ Class of compound tested ${ }^{\star}$} \\
\hline & & & & & Tannins & Saponins & $\begin{array}{l}\text { Flavonoids } \\
\text { (phenolics) }\end{array}$ & Alkaloids & Steroids \\
\hline 1 & G. ferrea & HOS 3425 & Amani-Tanga & $\begin{array}{l}\text { Root } \\
\text { Fruit } \\
\text { Stem }\end{array}$ & $\begin{array}{l}- \\
+ \\
- \\
\end{array}$ & $\begin{array}{l}- \\
- \\
-\end{array}$ & $\begin{array}{l}+ \\
+ \\
+ \\
\end{array}$ & $\begin{array}{l}- \\
- \\
- \\
\end{array}$ & $\begin{array}{l}- \\
- \\
-\end{array}$ \\
\hline 2 & G. edulis & HOS 3426 & Amani-Tanga & $\begin{array}{l}\text { Root } \\
\text { Stem }\end{array}$ & $\begin{array}{l}- \\
-\end{array}$ & $\begin{array}{l}- \\
-\end{array}$ & $\begin{array}{l}+ \\
+ \\
\end{array}$ & $\begin{array}{l}- \\
-\end{array}$ & $\begin{array}{l}+ \\
+ \\
\end{array}$ \\
\hline 3 & G. bifasciculata & FM 10135 & Kimboza-Morogoro & Stem & - & - & + & - & + \\
\hline 4 & G. buchananni & HOS 3427 & Amani-Tanga & $\begin{array}{l}\text { Root } \\
\text { Stem }\end{array}$ & $\begin{array}{l}+ \\
-\end{array}$ & $\begin{array}{l}- \\
-\end{array}$ & $\begin{array}{l}+ \\
+\end{array}$ & $\begin{array}{l}- \\
- \\
\end{array}$ & $\begin{array}{l}+ \\
+\end{array}$ \\
\hline 5 & G. semseii & HOS 3422 & Kihansi-Iringa & $\begin{array}{l}\text { Stem } \\
\text { Root } \\
\text { Fruit hulls } \\
\text { Seed }\end{array}$ & $\begin{array}{l}- \\
- \\
- \\
-\end{array}$ & $\begin{array}{l}- \\
- \\
- \\
-\end{array}$ & $\begin{array}{l}+ \\
+ \\
+ \\
+\end{array}$ & $\begin{array}{l}- \\
- \\
- \\
-\end{array}$ & $\begin{array}{l}+ \\
+ \\
- \\
-\end{array}$ \\
\hline 6 & G. volkensis & HOS 3424 & Amani-Tanga & Stem & - & - & + & - & + \\
\hline 7 & G. livingstoneii & HOS 3423 & Pugu Forest & $\begin{array}{l}\text { Root } \\
\text { Stem }\end{array}$ & $\begin{array}{l}- \\
-\end{array}$ & - & $\begin{array}{l}+ \\
+ \\
\end{array}$ & $\begin{array}{l}- \\
-\end{array}$ & $\begin{array}{l}+ \\
+ \\
\end{array}$ \\
\hline 8 & G. kingaensis & HOS 3429 & Lugoda-Iringa & Stem & - & - & + & - & + \\
\hline 9 & G. huillensis & HOS 3428 & Lugoda-Iringa & $\begin{array}{l}\text { Root } \\
\text { Stem }\end{array}$ & $\begin{array}{l}+ \\
- \\
\end{array}$ & $\begin{array}{l}- \\
-\end{array}$ & $\begin{array}{l}+ \\
+ \\
\end{array}$ & $\begin{array}{l}- \\
- \\
\end{array}$ & $\begin{array}{l}+ \\
+ \\
\end{array}$ \\
\hline
\end{tabular}

$+=$ Present; - = not detected

Garcinia bifasculata N. Robson, Garcinia buchananii Bak., Garcinia edulis Exell. Garcinia ferrea Pierre, Garcinia huillensis Welw. ex Oliv., Garcinia kingaensis Engl., G. livingstonei T. Anderson, Garcinia semseii Verdc and Garcinia volkensis. The voucher specimens are deposited in the Herbarium at the Department of Botany, University of Dar es Salaam, Tanzania.

\section{Preparation of extracts}

Ten grams (powder) of the specified part of each dried plant material were soaked in ethanol $(150 \mathrm{ml})$ for $48 \mathrm{~h}$ at room temperature. The ethanol extract was filtered and evaporated under vacuum on a rotary evaporator. The crude extracts were dissolved in DMSO for bioassay.

\section{Enzymes and chemicals}

Recombinant HIV-1 PR, substrate peptides and acety pepstatin, were purchased from Sigma Chemical Co., St. Louis, USA.

\section{Phytochemical screening test for the extracts}

The methods of Trease and Evans (1983); Harbourne (1983) to test for alkaloids, tannins, flavonoids, steroids and saponins were used.

\section{Test for flavonoids}

An amount $0.3 \mathrm{~g}$ of the extract was dissolved in $3 \mathrm{ml}$ of methanol and heated. A small magnesium metal was added to the mixture followed by the addition of a few drops of concentrated $\mathrm{HCl}$. The occurrence of a red or orange colouration was indicative of the flavonoids or any other phenolic compounds.

\section{Test for alkaloids}

About $0.5 \mathrm{~g}$ of the plant extract was dissolved in $5 \mathrm{ml}$ of $1 \%$ $\mathrm{HCl}$ and warmed on steam bath. The filtrate $(1 \mathrm{ml})$ was mixed with drops of Dragendorff's reagent. Reddish orange precipitation was considered as indicative of the presence of alkaloids.

\section{Test for tannins}

The extract $(1 \mathrm{~g})$ was dissolved in $20 \mathrm{ml}$ of distilled water 
Table 2. Anti-HIV-1 protease activity of crude extracts of some Garcinia species.

\begin{tabular}{|c|c|c|c|c|c|c|c|c|}
\hline \multirow{2}{*}{$\mathbf{S} / \mathbf{N}$} & \multirow{2}{*}{ Plant name } & \multirow{2}{*}{ Plant part } & \multicolumn{4}{|c|}{$\%$ inhibition at various concentrations $(\mu \mathrm{g} / \mathrm{ml})^{\star}$} & \multirow{2}{*}{$\begin{array}{c}\text { Regression equation } \\
\quad Y=A \operatorname{Ln}(x) \pm B\end{array}$} & \multirow{2}{*}{$\mathrm{IC}_{50}(\mu \mathrm{g} / \mathrm{mI})$} \\
\hline & & & 3 & 10 & 30 & 100 & & \\
\hline \multirow[t]{3}{*}{1} & G. ferrea & Root & - & $-22.1 \pm 4.8$ & $29.4 \pm 2.4$ & $87.9 \pm 6.4$ & $Y=47.785 \operatorname{Ln}(x)-132.47$ & 45.5 \\
\hline & & Fruit & - & $-4.4 \pm 2.3$ & $3.7 \pm 5.2$ & $94.8 \pm 1.3$ & $Y=43.601 \operatorname{Ln}(x)-118.46$ & 47.6 \\
\hline & & Stem & - & $12.1 \pm 1.1$ & $64.8 \pm 0.2$ & $85.5 \pm 4.3$ & $Y=31.643 \operatorname{Ln}(x)-54.603$ & 27.3 \\
\hline \multirow[t]{2}{*}{2} & G. edulis & Root & - & $-25.9 \pm 2.3$ & $17.6 \pm 5.5$ & $84.8 \pm 8.4$ & $Y=48.2 \operatorname{Ln}(x)-140.13$ & 51.7 \\
\hline & & Stem & - & $49.3 \pm 1.9$ & $72.5 \pm 2.5$ & $85.7 \pm 4.7$ & $Y=15.731 \operatorname{Ln}(x)+15.11$ & 9.2 \\
\hline 3 & G. bifasciculata & Stem & - & - & - & $-32.7 \pm 11$ & & $>100$ \\
\hline \multirow[t]{2}{*}{4} & G. buchananni & Root & - & - & - & $-6.3 \pm 4.4$ & & $>100$ \\
\hline & & Stem & - & - & - & $-1.8 \pm 5.1$ & & $>100$ \\
\hline \multirow[t]{4}{*}{5} & G. semseii & Stem & - & $24.9 \pm 2.0$ & $47.7 \pm 0.5$ & $91.2 \pm 3.5$ & $Y=28.911 \operatorname{Ln}(x)-44.746$ & 26.5 \\
\hline & & Root & - & $4.5 \pm 0.8$ & $71.5 \pm 4.9$ & $82.8 \pm 1.4$ & $Y=33.613 \operatorname{Ln}(x)-62.571$ & 28.5 \\
\hline & & Fruit hulls & - & $56.4 \pm 3.9$ & $81.8 \pm 2.5$ & $93.8 \pm 1.5$ & $Y=16.143 \operatorname{Ln}(x)+21.862$ & 5.7 \\
\hline & & Seed & - & $14.4 \pm 7.1$ & $38.4 \pm 4.3$ & $86.6 \pm 3.9$ & $Y=31.494 \operatorname{Ln}(x)-61.758$ & 34.8 \\
\hline 6 & G. volkensis & Stem & - & $-13.5 \pm 0.1$ & $-6.1 \pm 0.2$ & $86.5 \pm 3.4$ & $Y=44.007 \operatorname{Ln}(x)-128.9$ & 58.3 \\
\hline \multirow[t]{2}{*}{7} & G. livingstoneii & Root & - & $-2.3 \pm 5.4$ & $44.5 \pm 2.0$ & $87.0 \pm 4.0$ & $Y=38.727 \operatorname{Ln}(x)-90.012$ & 37.2 \\
\hline & & Stem & - & $23.1 \pm 2.4$ & $34.3 \pm 7.5$ & $89.5 \pm 3.4$ & $Y=29.108 \operatorname{Ln}(x)-51.059$ & 32.2 \\
\hline 8 & G. kingaensis & Stem & - & $37.6 \pm 0.6$ & $70.8 \pm 4.1$ & $94.4 \pm 1.0$ & $Y=24.587 \operatorname{Ln}(x)-16.889$ & 15.2 \\
\hline \multirow[t]{2}{*}{9} & G. huillensis & Root & - & - & - & $-17.5 \pm 3.2$ & & $>100$ \\
\hline & & Stem & - & - & - & $20.3 \pm 6.4$ & & $>100$ \\
\hline \multicolumn{3}{|c|}{ Acetyl pepstatin (+ve control) } & $50.2 \pm 1.4$ & $70.0 \pm 0.5$ & $82.4 \pm 0.4$ & $88.5 \pm 0.2$ & $Y=10.955 \operatorname{Ln}(x)+41.533$ & 2.2 \\
\hline
\end{tabular}

- = Not determined

and filtered. Three drops of $10 \%$ of $\mathrm{FeCl}_{3}$ were added to 2 $\mathrm{ml}$ of the filtrate. The appearance of blackish-blue or blackish-green colouration was indicative of tannins. Some $2 \mathrm{ml}$ of the filtrate was added, $1 \mathrm{ml}$ of bromine water and a precipitate was taken as positive for tannins.

\section{Test for saponins}

The $7 \%$ blood agar medium was used. The extract in methanol was applied with distilled water and methanol used as negative control while commercial saponin (BDH) solution was used as positive control. The plates were incubated at $35^{\circ} \mathrm{C}$ for $6 \mathrm{~h}$. A total haemolysis of the blood around the extract was indicative of saponins.

\section{Test for steroids}

About $0.5 \mathrm{~g}$ of the extract was dissolved in $3 \mathrm{ml}$ of $\mathrm{CHCl}_{3}$ and filtered. Concentrated $\mathrm{H}_{2} \mathrm{SO}_{4}$ was added to the filtrate. $A$ reddish brown colour was taken as positive for steroid ring.

\section{Assay of HIV-1 PR inhibitory activity}

This assay was modified from the previously reported method (Tewtrakul et al., 2003). In brief, the recombinant HIV-1 PR solution was diluted with a buffer composed of a solution containing $50 \mathrm{mM}$ of sodium acetate ( $\mathrm{pH} \mathrm{5.0),} 1$ $\mathrm{mM}$ ethylenediamine disodium (EDTA.2Na) and $2 \mathrm{mM} 2$ mercaptoethanol (2-ME) and mixed with glycerol in the ratio of 3:1. The substrate peptide, Arg-Val-Nle- $\left(\mathrm{pNO}_{2}-\right.$ Phe)-Glu-Ala-Nle- $\mathrm{NH}_{2}$, was diluted with a buffer solution of $50 \mathrm{mM}$ sodium acetate ( $\mathrm{pH}$ 5.0). Two microliters of plant extract and $4 \mathrm{ml}$ of HIV-1 PR solution $(0.025 \mathrm{mg} / \mathrm{ml})$ were added to a solution containing $2 \mathrm{ml}$ of $50 \mathrm{mM}$ buffer solution ( $\mathrm{pH} 5.0)$ and $2 \mathrm{ml}$ of substrate solution $(2 \mathrm{mg} / \mathrm{ml})$, and the reaction mixture $(10 \mathrm{ml})$ was incubated at $37^{\circ} \mathrm{C}$ for $1 \mathrm{~h}$. A control reaction was performed under the same conditions but without the plant extract. The reaction was stopped by heating the reaction mixture at $90^{\circ} \mathrm{C}$ for $1 \mathrm{~min}$. Subsequently, $20 \mathrm{ml}$ of sterilized water was added and an aliquot of $10 \mathrm{ml}$ was analyzed by HPLC using RP-18 column (4.6 x $150 \mathrm{~mm}$ I.D., Supelco 516 C-18-DB $5 \mathrm{~mm}$, USA). Ten microlitres of the reaction mixture was injected 
to the column and gradiently eluted with acetonitrile (15-40\%) and $0.2 \%$ trifluoroacetic acid (TFA) in water, at a flow rate of $1.0 \mathrm{ml} / \mathrm{min}$. The elution profile was monitored at $280 \mathrm{~nm}$. The retention times of the substrate and $\mathrm{p}-\mathrm{NO}_{2}$-Phe-bearing hydrolysate were 11.25 and 9.72 min, respectively. The inhibitory activity on HIV-1 PR was calculated as follows:

$\%$ inhibition $=\left(A_{\text {control }}-A_{\text {sample }}\right) \times 100 / A_{\text {control }}$

whereas $A$ is a relative peak area of the product hydrolysate. Acetyl pepstatin was used as a positive control.

\section{Statistical analysis}

The results of anti-HIV-1 PR activity were expressed as means \pm SD of three determinations. The $\mathrm{IC}_{50}$ values were calculated using the Microsoft Excel programme at which the logarithmic regression equations were obtained (Table 2).

\section{RESULTS AND DISCUSSION}

The phytochemical screening conducted on Garcinia extracts collected in Tanzania revealed the presence of mainly flavonoids (phenolic compounds) and some steroids (Table 1). These compounds are widely reported in the genus Garcinia having novel and known molecular structures (Oliveira et al., 1999, Mbwambo et al., 2006, Nyemba et al., 1990). It is therefore believed that the potential bioactivities noted in this study may have been contributed by these two classes of compounds.

Furthermore, investigation of ethanol extracts from some Garcinia species for their HIV-1 protease (HIV-1 PR) inhibitory activities using high performance liquid chromatography (HPLC) was carried out. Among the tested samples, the fruit hulls of $G$. semseii showed the most potent inhibitory activity against HIV-1 PR with an $I_{50}$ value of $5.7 \mu \mathrm{g} / \mathrm{ml}$, followed by the stem bark extracts of $G$. edulis and $G$. kingaensis with $\mathrm{IC}_{50}$ values of 9.2 and $15.2 \mu \mathrm{g} / \mathrm{ml}$, respectively (Table 2). Other crude extracts exhibited moderate to mild anti-HIV-1 PR activity $\left(\mathrm{IC}_{50}=26.5->100 \mu \mathrm{g} / \mathrm{ml}\right)$. Acetyl pepstatin, a positive control, possessed anti-HIV-1 PR activity with an $\mathrm{IC}_{50}$ value of $2.2 \mu \mathrm{g} / \mathrm{ml}$. Calanolide $A$, a kind of coumarin, isolated from Calophyllum lanigerum (Clusiaceae family) has been reported to possess anti-HIV-1 activity (Ma et al., 2008) as well as the compounds from $C$. braziliense leaves (Reyes et al., 2004). Therefore the plants in this study which are all in the Clusiaceae family may have potential to be developed as anti-HIV-1 agents, especially G. semseii (Fruit hulls), G. edulis (stem) and G. kingaensis (stem). Regarding chemical constituents of Garcinia species, it has been recently reported that polyisoprenylated benzophenones, semsinones A-C, have been isolated from the stem bark of $G$. semseii (Magadula et al., 2008). Some polyisoprenylated benzophenone derivatives isolated from Clusia torresii such as clusianone and 7-epi-clusianone have been reported to exhibit marked anti-HIV-1 activity (Piccinelli et al., 2005).
Since G. semseii showed the most potent anti-HIV-1 PR effect in the present study $\left(\mathrm{IC}_{50}=5.7 \mu \mathrm{g} / \mathrm{ml}\right)$, prenylated benzophenone derivatives might be responsible for antiHIV-1 PR activity of this plant. Hence, these plants are the potential candidates as sources of ingredients for drug formulations for the treatment of HIV/AIDS and other related illness. The isolation of active compounds from $G$. semseii fruit hulls and other active extracts will be further investigated.

\section{ACKNOWLEDGEMENTS}

The authors wish to thank Mr. Haji O. Suleiman of the Botany Department, University of Dar es Salaam, Tanzania for collection and identification of the plant materials and the Faculty of Pharmaceutical Sciences, Prince of Songkla University, Songkhla, Thailand, for laboratory facilities. This study was supported by the International Foundation for Sciences (IFS), Stockholm, Sweden and the Organisation for the Prohibition of Chemical Weapons (OPCW), the Hague through a grant number F/4572-1 extended to JJM.

\section{REFERENCES}

Borman AM, Paulous S, Clavel F (1996). Resistance of HIV-1 protease inhibitors: Selection of resistance mutations on the presence and absence of the drug. J. Genet. Virol. 77: 419-426.

Chen SX, Wan M, Loh BN (1996). Active constituents against HIV-1 protease from Garcinia mangostana. Planta Medica. 62: 381-382.

Gustafson KR, Blunt JW, Munro MHG, Fuller RW, Mckee TC, Cardellina JH, II, McMahon JB, Cragg GM, Boyd MR (1992). Tetrahedron. 48: 10093-10102.

Harbourne JB (1983). Phytochemical Methods: A Guide to Modern Technique of plants Analysis. Chapman and Hall, London.

Kohl NE, Emini EA, Schleif WA (1988). Active human immunodeficiency virus protease in required for viral infectivity. Pro. Natl. Acad. Sci. USA. 85: 4686-4690.

Ma T, Gao Q, Chen Z, Wang L, Liu G (2008). Chemical resolution of calanolide $A$, cordatolide $A$ and their 11-demethyl analogues. Biol. and Med. Chem. Lett. 18: 1079-1083.

Magadula JJ, Kapingu MC, Bezabih M, Abegaz BM (2008). Polyisoprenylated benzophenones from Garcinia semseil (Clusiaceae). Phytochem. Lett. 1: 215-218.

Mbwambo ZH, Kapingu MC, Moshi MJ, Machumi F, Apers S, Cos P, Ferreira D, Marais JPJ, Berghe DV, Maes L, Vlietinck A, Pieters L (2006). Antiparastic Activity of some Xanthones and Biflavonoids from the root bark of Garcinia livingstonei. J. Nat. Prod. 69:369-372.

Nyemba AM, Mpondo TN, Connolly JD, Rycroft DS (1990). Cycloartane derivatives from Garcinia lucida. Phytochem. 29: 994-997.

Oliveira CMA, Porto ALM, Biurich V, Marsaioli AJ (1999). Two prenylated benzophenones from the floral resins of three Clusia species, Phytochem. 50: 1073-1079.

Oroszlam S (1989). Biosynthesis and proteolytic processing of retroviral proteins: an overview. Current Communications in molecular biologyviral proteinases as targets for chemotherapy. Cold Spring Harbor laboratory press, New York, pp. 87-100.

Piccinelli AL, Cuesta-Rubio O, Chica MB, Mahmood N, Pagano B, Pavone M, Barone V, Rastrelli L (2005). Structural revision of clusianone and 7-epi-clusianone and anti-HIV-1 activity of polyisoprenylated benzophenones. Tetrahedron. 61: 8206-8211.

Reyes MH, Basualido MC, Abe F, Estrada MJ, Soler C, Chilpa RR (2004). HIV-1 inhibitory compounds from Calophyllum brasiliense leaves. Biol. Pharm. Bull. 27: 1471-1475. 
Tewtrakul S, Subhadhirasakul S, Kummee S (2003). HIV-1 protease inhibitory effects of medicinal plants used as self medication by AIDS patients. Songklanakarin J. Sci. Technol. 25: 239-243.

Trease GE, Evans WC (1983). Pharmacognosy. 14th Ed, Publ. Brown Publications.
UN-AIDS Report, HIV and AIDS statistics and features, in 2005 and 2007. 